\title{
Bird fauna encountered at the main campus of the Islamic University of Gaza, Gaza City, Palestine
}

\author{
ABDEL FATTAH N. ABD RABOU \\ Department of Biology, Faculty of Science, Islamic University of Gaza. Gaza Strip, Palestine. email: arabou@ iugaza.edu.ps
}

Manuscript received: 10 January 2019. Revision accepted: 31 January 2019.

\begin{abstract}
Abd Rabou AN. 2019. Bird fauna encountered at the main campus of the Islamic University of Gaza, Gaza City, Palestine. Biodiversitas 20: 604-614. Birds are the most prominent and widespread wildlife species of both natural and urban environments worldwide. The strategic geographic position of Palestine at the meeting point of the three continents; Asia, Africa and Europe, is very crucial for the country's bird diversity. The Gaza Strip has never been studied for bird fauna in its urban environments. Thus, the current study comes to survey the bird fauna at the main campus $\left(82,000 \mathrm{~m}^{2}\right)$ of the Islamic University of Gaza (MC-IUG) as an urban environment. Birds were monitored using direct observations and binoculars for the lasted five years. Bird guidebooks and professional cameras were used throughout the succeeding stages of the study. A total number of 56 bird species, belonging to 26 families and 11 orders were encountered throughout the study at MC-IUG. Passeriformes was the largest order and comprised 35 (62.5\%) of the recorded bird species, while the non-passerines constitute the remaining 21 species (37.5\%). Muscicapidae was the largest among the recorded families, which was represented by 9 species (16.1\%), followed by 8 species of Fringillidae (14.3\%) and 5 species of Laniidae (8.9\%). Finally, the greening strategy of the Gaza Strip should be adopted by Gazans and the local authorities due to the crucial role of vegetation cover in attracting more biodiversity components; especially bird fauna.
\end{abstract}

Keywords: Birds, Gaza City, Gaza Strip, IUG, Palestine

\section{INTRODUCTION}

Birds (class Aves), the master of air, are the most prominent and widespread species of terrestrial and aquatic vertebrate fauna and occupy most of the global environments (Pomeroy 1992 and Bibby et al. 1998). They are so well studied because they are much more visible to people every day in streets and gardens and are aesthetically more attractive than many other animals (Brooke and Birkhead 1991). They form vital parts of food chains and food webs in ecosystems in addition to their important role as potential pollinators and bio-indicators (Rudra 2013). Frugivore birds are good seed dispersal agents among vertebrates (Corlett 2017). The abundance of bird population has been found to change considerably due to anthropogenic activities (Bock et al. 1999; Dunn 2002; Gilroy et al. 2016). Urbanization, industrial expansion, swamp drying and extensive and widespread use of chemical pesticides are major threats facing bird fauna and the other wildlife categories (Liven-Schulman et al. 2004).

The strategic geographical location of Palestine $(27,000$ $\mathrm{km}^{2}$ ) between the three continents Asia, Africa and Europe is an important route for migratory bird fauna. Every year, millions of migratory birds pass through the skies of Palestine, following three migration routes represented by the coast, the coastal plain, the mountains of Palestine and the Jordan River. Palestine has more than 500 bird faunistic species inhabiting all types of terrestrial and aquatic ecosystems and habitats, including mountainous and coastal landscapes and the Negev Desert (UNEP 2003 and Perlman and Meyrav 2009).

The Gaza Strip, which covers an area of $365 \mathrm{~km}^{2}$ (about
$1.5 \%$ of the total area of Palestine) and has a population of about two million, is located on the southernmost coast of Palestine along the Mediterranean Sea. The Gaza Strip has a diversity of both aquatic and terrestrial birds, whether resident or migratory because of its diversity of ecosystems (The Project for the Conservation of Wetland and Coastal Ecosystems in the Mediterranean Region - MedWetCoast 2003; Abd Rabou 2005; Abd Rabou et al. 2007), which are represented by the marine and coastal environments, Wadi Gaza, sand dunes, Al-Mawasi area, green spaces, agricultural orchards, border areas, wastewater treatment plants, solid waste landfills, etc. These environments introduce different values to bird fauna including mating, nesting, resting, roosting, mimicry, protection and food sites (Abd Rabou et al. 2007; Abd Rabou 2011a).

In spite of this valuable bird diversity in the Gaza Strip, wildlife hunters usually hunt different categories of bird species, such as the European Goldfinch, Chukar, Raptors, etc. In the autumn season of each year, the Gazans erect fishing nets along the coast of the Gaza Strip in order to catch the migratory Common Quail (Coturnix coturnix), which is characterized by its delicious meat (Abd Rabou et al. 2007; Abd Rabou 2011b; UNEP 2003). The importance of the Common Quail comes from the fact that it is a Quranic bird (Abd Rabou 2011b; Marwat et al. 2014); mentioned as Al-Salwa in three positions of the Holy Quran.

A lot of studies in different countries have been carried out on bird fauna surveys in various natural and seminatural ecosystems like oases, jungles, parks and nature reserves. Examples included the counties of India (Guptha et al. 2015), Turkey (Perktas and Ayas 2005), Jordan (Evans et al. 2005), Tunisia (Selmi and Boulinier 2003), 
Sudan (Hamad 1998; Yousif 2012; Mahmoud et al. 2015; Sulieman et al. 2016) and many others. Locally, many scientific studies have recorded a relatively high incidence of bird fauna, with most of them were encountered in Wadi Gaza Nature Reserve and related environments (MedWetCoast 2003; Abd Rabou 2005; Yassin et al. 2006; Abd Rabou et al. 2007). In addition, Abd Rabou (2011b) recorded as many as 56 bird faunistic species caged in the zoological gardens scattered throughout the Gaza Strip.

Studies on bird fauna prevailing in the urban environments of the Gaza Strip seem to be lacking. Accordingly, the current study aimed to survey the bird fauna prevailing at the main campus of the Islamic University of Gaza (MC-IUG) as an urban environment studded with many forms of vegetation (trees, shrubs and herbs) and buildings. The importance of the current study comes from the fact that it is the first dealing with urban animal biodiversity in the Gaza Strip. The study demonstrates the importance and role of urban vegetations in attracting various categories of biodiversity; mainly bird fauna. No doubts that such a bird diversity is very crucial in introducing aesthetic, recreational and ethical values to the Gazan community, which suffers from tense atmosphere in times the whole Gaza Strip is lying under harsh and severe military, political, economic and siege conditions imposed by the Israeli occupation since decades.

\section{MATERIALS AND METHODS}

\section{Gaza Strip}

The Gaza Strip (Figure 1.A), which has an area of 365 $\mathrm{km}^{2}$, lies in the southern part of the Palestinian coast along the eastern shore of the Mediterranean basin (UNEP 2003). The Gaza Strip has a population of about 2 million, mostly refugees from the 1948 Nakba. The population density is about 5,500 inhabitants per square kilometer, making the Gaza Strip one of the most densely populated areas in the world. The Gaza Strip is composed of five governorates: North Gaza, Gaza, Middle, Khan Younis and Rafah. The Gaza City is the largest in the Gaza Strip, having a population of more than 600,000. The Gaza Strip includes eight Palestinian refugee camps run by the United Nations Relief and Works Agency for Palestine Refugees in the Near East (UNRWA), namely the Jabalia, Shati, Bureij, Maghazi, Nuseirat, Deir al-Balah, Khan Younis and Rafah camps.

The Gaza Strip is characterized by its semi-dry Mediterranean climate, which is hot in summer and cold in winter. The average temperatures in the Gaza Strip range from $25^{\circ} \mathrm{C}$ in summer to $13^{\circ} \mathrm{C}$ in winter. The average annual rainfall is $300 \mathrm{~mm}$. The daily relative humidity fluctuates between $65 \%$ and $85 \%$ in summer and between $60 \%$ and $80 \%$ in winter. Sand dunes are the main feature of the western part of the Gaza Strip, while the clay and clayey lands predominate in the eastern part (Euroconsult and IWACO 1994; UNEP 2003).

\section{The Islamic University of Gaza as a study area}

The Islamic University of Gaza (IUG), which was established in 1978, is an independent academic institution supervised by the Ministry of Higher Education. The MCIUG has an area of 82 dunums or $82,000 \mathrm{~m}^{2}$ (one dunum equals $1000 \mathrm{~m}^{2}$ ) (Figure 1.B).

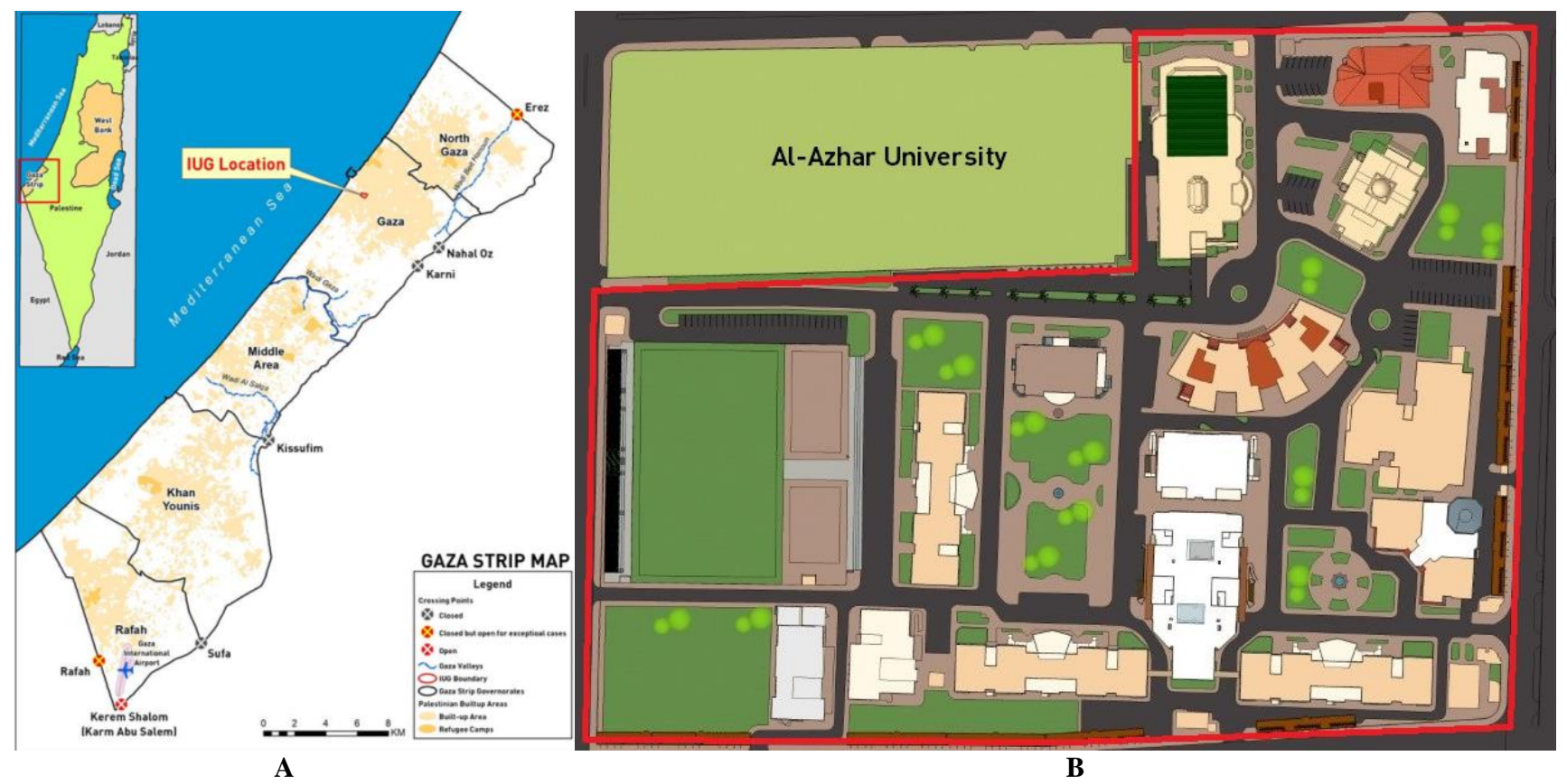

Figure 1. A. The position of the Gaza Strip in Palestine, with the location of IUG is presented. B. A schematic structure of MC-IUG $\left(82,000 \mathrm{~m}^{2}\right)$, surrounded by red line, showing its buildings and green spaces that attract different categories of bird fauna 


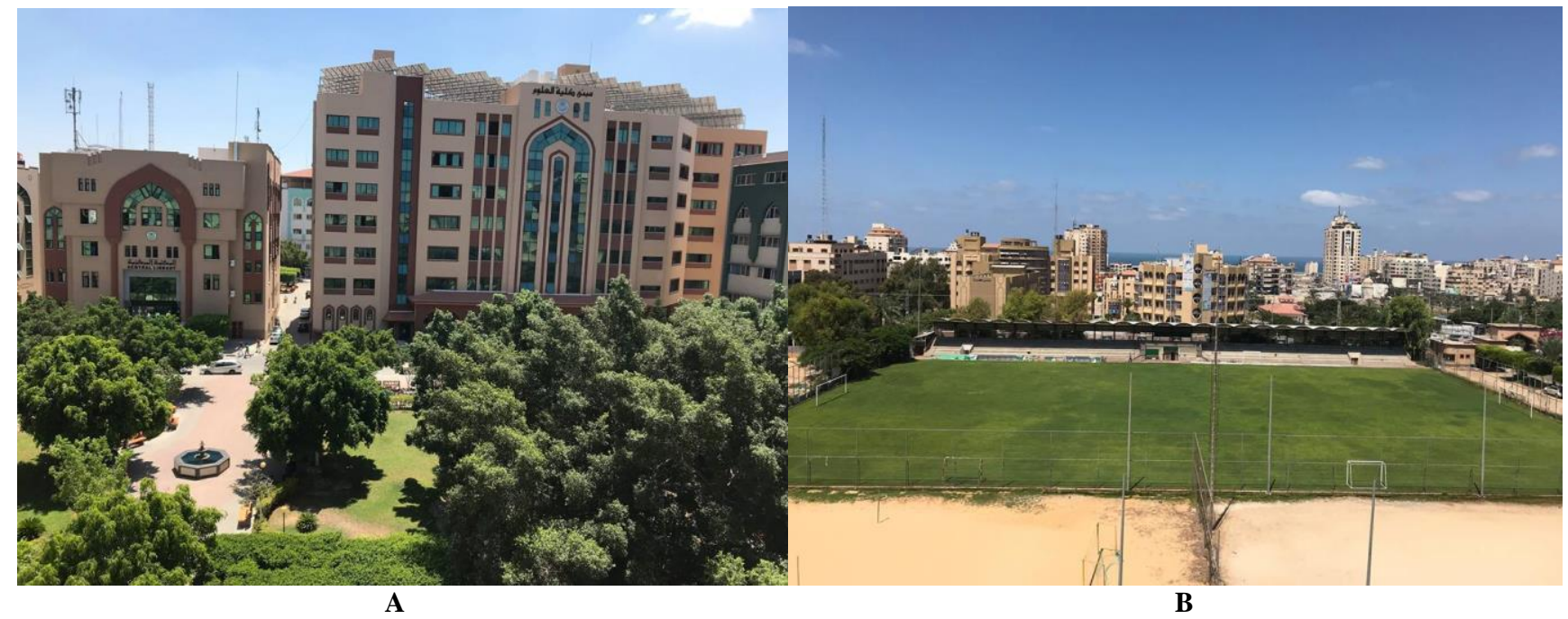

Figure 2. A. The green spaces of MC-IUG are studded with tens of native and exotic shrub and tree species. B. The green grassy playground of MC-IUG is a site of roaming and feeding for many bird species

Table 1. Important trees and shrubs supporting the occurrence and diversity of bird fauna at MC-IUG

\begin{tabular}{|c|c|c|}
\hline Scientific or latin name & Common name & Arabic name \\
\hline Araucaria heterophylla & Norfolk Island Pine (Christmas Tree) & شجرة الميلاد (الأروكاريا) \\
\hline Cupressus sempervirens & Evergreen Cypress & 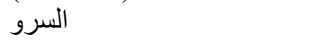 \\
\hline Phoenix dactylifera & Date Palm & نخيل البلح \\
\hline Washingtonia filifera & California Fan Palm & نخيل و اشنطونياً \\
\hline Poinciana regia & Royal Poinciana & 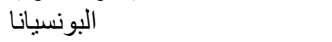 \\
\hline Hibiscus rosa-sinensis & Chinese Hibiscus (China Rose) & الكركدية الأحمر (الورد الصيني) \\
\hline Eucalyptus camaldulensis & River Redgum & الكينيا (الكافور) \\
\hline Callistemon citrinus & Red Bottlebrush (Callistemon) & 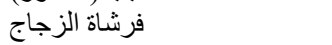 \\
\hline Ficus elastica & Rubber Fig & التين المطاطي (الكاوتشوك) \\
\hline Ficus nitida & Weeping Fig & الغار الهندي (نيتدا) \\
\hline Ficus benjamina & Benjamin Fig & التين المتهدل \\
\hline Olea europea & Olive Tree & 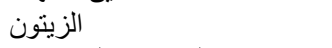 \\
\hline Bougainvillea spectabilis & Veranera & الجهنمية (المجنونة) \\
\hline
\end{tabular}

More than one hundred of academic programs in different disciplines are currently offered by IUG to the Palestinian society. The IUG also provides all available resources, including the most up-to-date technology in service of the education process. It provides its students with an academic atmosphere rich in various types of native and exotic grass, shrub and tree plants (Table 1 and Figure 2.A), which are somewhat analogous to the plants grown on the urban streets, orchards, gardens and parks of the Gaza Strip (Abbas 2016; Radwan 2017; Abd Rabou and Radwan 2017; Abd Rabou 2018). Such urban plants attract many biodiversity elements; particularly the bird fauna. Moreover, the MC-IUG is lucky in owing a green grassy playground of a considerable area that is crucial for attracting many bird species, particularly passerines (Figure 2.B). It is worth mentioning that the IUG has achieved many advanced rankings in the international classification of universities according to the standards of sustainability and green environment. Such standards are crucial in increasing the biodiversity level as well as in enhancing the educational quality.

\section{Procedure}

The current study, which lasted 5 years, was based on continuous direct observations and monitoring of bird fauna roaming at MC-IUG and its neighboring urban environments. Professional binoculars, when and where needed, were used for bird watching and identification. A number of available local, regional and international avian guidebooks have been used in the identification process of bird species (Baha El-Din and Atta 1990; Disi and HatougBoran 1990; Harrison and Greensmith 1993; Porter et al. 1996; Shirihai 1996; Abu Shammalah and Baha El-Din 1999; Forshaw et al. 1999; Jonsson 1999; Cottridge and Porter 2000). 


\section{Photography and data analysis}

During the years of observation, many photographs concerning the bird fauna of MC-IUG and other parallel urban environments in the Gaza City were taken for documentary and confirmation purposes. Statistical data were analyzed using the SPSS (Statistical Package for Social Sciences, Chicago, Illinois). Graphs were plotted using Microsoft Excel 2010.

\section{RESULTS AND DISCUSSION}

\section{Bird fauna recorded at MC-IUG}

The results of the present study pointed out that a total number of 56 bird faunistic species, belonging to 26 families and 11 orders, occurring at MC-IUG (Table 2). Passeriformes was the largest order and comprised 35 $(62.5 \%)$ of the recorded bird species. The remaining 21 species $(37.5 \%)$ represented the non-passerines which form the other bird orders (Figure 3). Muscicapidae was the largest among the recorded families, which was represented by 9 species (16.1\%), followed by 8 species of Fringillidae (14.3\%) and 5 species of Laniidae (8.9\%).

\section{Notes on selected bird species}

The following paragraphs represent notes on some important species of birds encountered at MC-IUG.

\section{Cattle Egret (Bubulcus ibis)}

The Cattle Egret (known locally as Abu Ghardan) is the most occurring heron species in the Gaza Strip. It is commonly seen in considerable numbers in agricultural fields, Wadi Gaza, wastewater treatment plants and solid waste dumps or landfills in the Gaza Strip. These places serve a wide range of prey, such as insects, moths, spiders, frogs, earthworms, etc. The bird was rarely seen landing in the grassy playground of IUG. Instead, the bird was commonly seen flying in small groups ranging from 5 to 10 individuals in the sky of MC-IUG and other areas of the Gaza Strip.

\section{Black Kite (Milvus migrans)}

The Black Kite is one of the most widespread birds of prey in the Gaza Strip due to its dense presence near the permanent and temporary solid waste landfills. It is an opportunistic hunter and is also a scavenger feeder. The bird was sometimes seen hovering in the sky of MC-IUG and its environs in search of food. Some Gazans used to catch the species using different hunting means in order to raise it at their homes or to sell it to Gaza zoos, and therefore it is the most captive bird of prey occurring at the local zoos of the Gaza Strip.

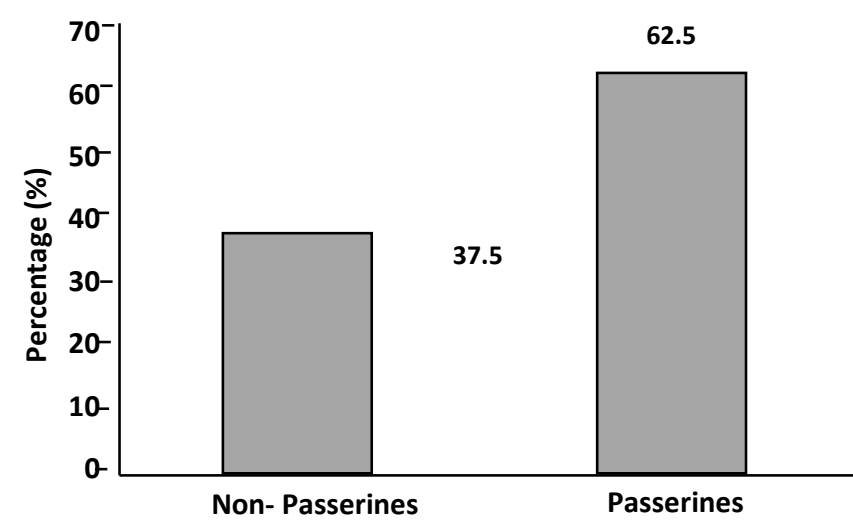

Figure 3. A graphic model showing the percentages of passerine and non-passerine bird fauna prevailing at MC-IUG

Table 2. A List of the bird fauna prevailing at MC-IUG

\begin{tabular}{|c|c|c|c|}
\hline Family & Scientific / Latin name & Common name & Arabic / local name \\
\hline $\begin{array}{l}\text { Pelecaniformes عيات } \\
\text { Ardeidae } \\
\text { البلشونية }\end{array}$ & Bubulcus ibis & Cattle Egret & أبو قردان \\
\hline $\begin{array}{l}\text { Accipitriformes ابرة الكواسر Accipitridae } \\
\text { اسر }\end{array}$ & $\begin{array}{l}\text { Milvus migrans } \\
\text { Elanus caeruleus } \\
\text { Buteo buteo } \\
\text { Buteo rufinus }\end{array}$ & $\begin{array}{l}\text { Black Kite } \\
\text { Black-winged Kite } \\
\text { Common Buzzard } \\
\text { Long-legged Buzzard }\end{array}$ & 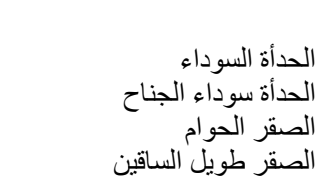 \\
\hline $\begin{array}{l}\text { Falconiformes قريات } \\
\text { Falconidae } \\
\text { الصقرية }\end{array}$ & $\begin{array}{l}\text { Falco naummani } \\
\text { Falco tinnunculus } \\
\text { Falco subbuteo }\end{array}$ & $\begin{array}{l}\text { Lesser Kestrel } \\
\text { Common Kestrel } \\
\text { Eurasian Hobby }\end{array}$ & 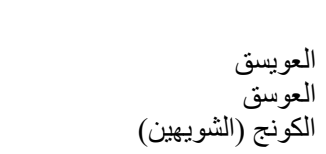 \\
\hline $\begin{array}{l}\text { Charadriiformes } \\
\text { Charadriidae } \\
\text { القطقاطية }\end{array}$ & Vanellus spinosus & Spur-winged Plover & الزقزاق الثامي (القطا) \\
\hline $\begin{array}{l}\text { Columbiformes يات } \\
\text { Columbidae } \\
\text { الحمامية }\end{array}$ & $\begin{array}{l}\text { Columba livia } \\
\text { Streptopelia turtur } \\
\text { Streptopelia senegalensis }\end{array}$ & $\begin{array}{l}\text { Rock Dove (Pigeon) } \\
\text { Turtle Dove } \\
\text { Laughing (Palm - Senegal) Dove }\end{array}$ & 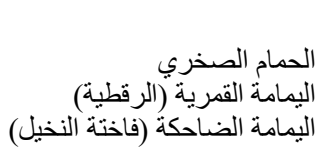 \\
\hline
\end{tabular}


رتبة البيغائيات Psittaciformes Psittacidae البَّبغاويَّة

ببغاء الذُرَّة (البيغاء ورديّ الطوق)

رنبة البوميات Strigiformes

Tytonide

Tyto alba

Barn Owl

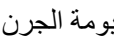

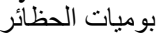

Strigidae

Otus scops

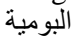

Athene noctua

Coraciiformes رتبة الثقراقيات

Coraciidae

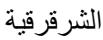

Alcedinidae

القاوندية

Meropidae

الوروارية

Coracius garrulus

Halcyon smyrnensis

Merops apiaster

رتبة قرنيات المنقار Bucerotiformes

Upupidae

Upupa epops

الهدهدية

رتبة النقاريات أو القرعيات Piciformes

Picidae

Dendrocopos syriacus اللوائية

\section{Passeriformes
Hirundinidae
السنونية \\ Motacillidae \\ الفتاحية (الذعريات) \\ Pycnonotidae \\ البلبلية \\ Muscicapidae \\ خاطفات الذباب أو \\ الشوربية (المذبابيات)}

Cisticolidae

الهوازج الرشيقة

Sylviidae

الخناثع (الدخل)

Phyllscopidae

خناشع ورقية

Nectariniidae

المغثريات

Laniidae

الصرود (الدقناثيات)

Corvidae

الغرابية

Sturnidae

الزرازير

Passeridae

العصفورية

Fringillidae

الحساسين
Hirundu rustica

Motacilla flava

Motacilla alba

Pycnonotus xanthopygos

Cercotrichas galactotes

Erithacus rubecula

Luscinia svecica

Phoenicurus phoenicurus

Saxicola torquata

Oenanthe isabellina

Oenanthe oenanthe

Oenanthe hispanica

Muscicapa striata

Prinia gracilis

Sylvia melanocephala

Sylvia curruca

Phylloscopus collybita

Nectarinia osea

Lanius collurio

Lanius senator

Lanius nubicus

Lanius senator

Lanius nubicus

Garrulus glandarius

Corvus cornix

Acridotheres tristis

Passer domesticus

Fringilla coelebs

Serinus serinus

Serinus syriacus

Carduelis chloris

Carduelis carduelis

Carduelis spinus

Carduelis cannabina

Rhodospiza obsoleta
European Scops Owl

Little Owl

أم قويق (البومة الصغيرة

European Rollar

White-breasted Kingfisher

European Bee-eater

Hoopoe

Syrian Woodpecker

Barn Swallow

Yellow Wagtail

White Wagtail

Yellow-vented Bulbul

Rufous Bush Robin

European Robin

Bluethroat

Common Redstart

Stonechat

Isabelline Wheatear

Northern Wheatear

Black-eared Wheatear

Spotted Flycatcher

Graceful Prinia (Warbler)

Sardinian Warbler

Lesser Whitethroat

Chiffchaff

Palestine Sunbird

Red-backed Shrike

Lesser grey Shrike

Great grey Shrike

Woodchat Shrike

Masked Shrike

Eurasian Jay

Hooded Crow

Common (Indian) Mynah

House Sparrow

Chaffinch

European Serin

Syrian Serin

Green Finch

Goldfinch

Siskin

Linnet

Desert Finch

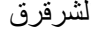

السماك أبيض الصدر (القاوند)

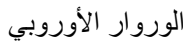

الهدهد

نق الخشب السوري

السنونو (عصفور الجنة)

الذعرة الصفر اء (السفرية) الذعرة البيضاء (الكركز) البلبل أصفر العجز البضاء

أبو الحناء الأحرش أبو الحناء (الحمرية) المسهر (أزرق الزور) الأحة) الحمبر اء الدبساء الزباء

أبلق الرعيان (القليعي الأحمر)

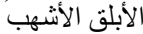

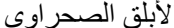

الأبلق أسود الأذن (أبو بليق إسباني)

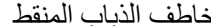

الفسية (الهازجة الرشيقة)

ننشع أو دخلة سردينبا

لنخلة بيضاء الحنجرة صغيرة النقشارة الذهبية

عصفور الثمس الفلسطيني

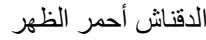

الدقناش الرمادي الصغير الزير

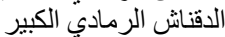

الدقاش الثنامي (الصُرَد أحمر القنة)

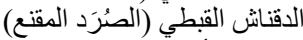

الزريقي (أبو زريقي)

الغر اب البلدي الرمادي الزئي

العصفور المنزلي (الدوري)

الزرعي (الصغنج)

النعار الأوروبي (البسبوس) النعار السوري الأنيري

الخضر (الخضيري) الحسون الذهبي الخبري

حسون الثوك (الطرنجان) العصفور التفاحي

الحسون الصحر آوي (الهرد) 


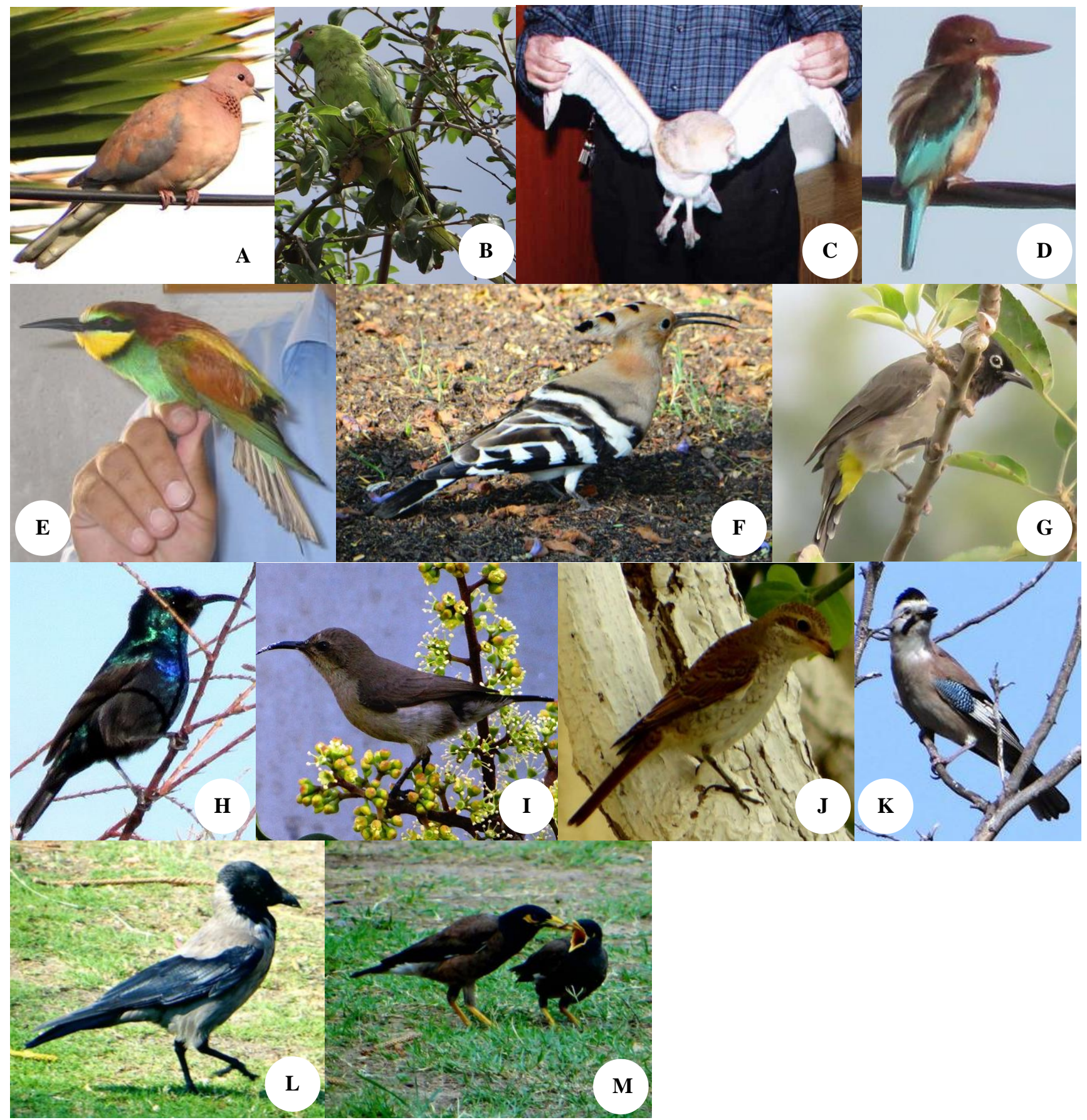

Figure 4. A. Laughing Dove (Streptopelia senegalensis), B. Ring-necked Parakeet (Psittacula krameri), C. A Barn Owl (Tyto alba) specimen caught at the biology labs of IUG, D. White-breasted Kingfisher (Halcyon smyrnensis), E. A live European Bee-eater (Merops apiaster) specimen displayed to students at the biology labs of IUG, F. Hoopoe (Upupa epops), G. Yellow-vented Bulbul (Pycnonotus xanthopygos), H. The Palestine Sunbird (Nectarinia osea) - Male: An endemic bird in Palestine, I. The Palestine Sunbird (Nectarinia osea) - Female: An endemic bird in Palestine, J. Red-backed Shrike (Lanius collurio), K. Eurasian Jay (Garrulus glandarius), L. Hooded Crow (Corvus corone), M. Indian or Common Mynah (Acridotheres tristis). Note:m Photographs of A, B, K by Mandy and Lara M. Sirdah in 2018; C, E, by author in 2018; F, I, J, L, M. by Mandy and Lara M. Sirdah in 2017; D, by AW Dardonah in 2017; G, H, by A.W. Dardonah in 2016

\section{Lesser Kestrel (Falco naummani)}

The Lesser Kestrel is widely distributed in the Palestinian urban environments. It has the smallest size if compared to other falcons occurring in Palestine. The bird was intermittently seen hovering in the sky of MC-IUG and its environs. From an ecological point of view, this globally threatened species, along with the Kestrel (Falco tinnunculus) and Hobby (Falco subbuteo), are often hunted by bird hunters and even children in the Gaza Strip in a total absence of the legislations prohibiting such hunting 
practices. Accordingly, many bird of prey species have been frequently sold at bird shops and many public markets, thus, threatening their local populations.

\section{Spur-winged Plover (Vanellus spinosus)}

The Spur-winged Plover is much spread in different aquatic and agricultural environments of the Gaza Strip including Al-Mawasi ecosystem, Wadi Gaza, Wadi Beit Hanoun and the existing wastewater treatment plants. In several occasions, the ground nests of the bird, containing 3 -4 eggs, have been observed and photographed. This bird is a nuisance, having a loud voice, in an attempt to defend its territory. In spite of its aquatic nature, the bird is sometimes seen flying in the sky of MC-IUG or standing for varying periods of time on solid objects prevailing at MC-IUG and its close environs.

\section{Laughing or Palm Dove (Streptopelia senegalensis)}

The Laughing Dove (Figure 4.A) is commonly seen throughout the year in various natural and urban environments in the Gaza Strip, including orchards, home yards, and gardens of the Palestinian institutions. Despite seeing it in MC-IUG, the bird builds its nests on the buildings and trees of the IUG and the neighboring urban environs. The bird also nests in residential dwellings and sometimes on their balconies. Tens of this species are commonly seen caged at Gaza zoos or sold at pet shops. In addition to the other local dove and pigeon species, the Laughing Dove is often hunted locally for its eggs, meat or sometimes for no clear reason.

\section{Ring-necked Parakeet (Psittacula krameri)}

It was rare to see the Ring-necked Parakeet (4.B) in the boundaries of MC-IUG; this social bird is rife in the fields and public parks supported by high trees and shrubs. It is characterized by its green color and its beautiful voice, which makes it an overhunting target for breeding and sale purposes in the pet shops prevailing in the Gaza Strip.

\section{Barn Owl (Tyto alba)}

The Barn Owl is the most common owl species prevailing in all environments of the Gaza Strip, especially those close to dwellings and human activities. The owl is nocturnal in the sense that it is active at night to attack and hunt mice, small animals, and many wild and domestic birds. Accordingly, some citizens consider the species as an undesirable pest. The owl is characterized by its heartshaped face and its white and gold colors. Many individuals of the species were captured during the day while hiding themselves at the biology laboratories of the IUG (Figure 4.C). In addition, the Barn Owl is commonly found stuffed at Palestinian universities' laboratories or caged at zoos prevailing in the Gaza Strip.

\section{White-breasted Kingfisher (Halcyon smyrnensis)}

The White-breasted Kingfisher (Figure 4.D) is one of three kingfisher species prevailing in the Gaza Strip. Unlike the Common Kingfisher (Alcedo atthis) and Pied Kingfisher (Ceryle rudis), which are commonly found near water bodies, the White-breasted Kingfisher is common in many urban environments including MC-IUG. It is often observed by the Palestinians throughout the year in gardens, public parks and green spaces. The species is characterized by its bright blue colors and its high and distinctive voice. The bird nests in holes found in land slopes and cliffs throughout the Gaza Strip.

\section{European Bee-eater (Merops apiaster)}

The European Bee-eater (Figure 4.E) is one of the most beautiful social birds in the Gaza Strip. It is commonly seen in many agricultural, natural environments and urban environments in the Gaza Strip. It was seen many times hovering high in the sky of the MC-IUG in search of its food. The bird feeds on a variety of insects, especially the Honeybee (Apis mellifera), as is evident from its name.

\section{Hoopoe (Upupa epops)}

The Hoopoe (Figure 4.F) is common in many ecosystems in the Gaza Strip, especially those having barren lands or low-lying vegetation. It is commonly seen searching food in the playground and other low-vegetated areas of MC-IUG. The Hoopoe feeds on insects and other invertebrates. Therefore, Gazan farmers consider the bird as an eco-friend because of its feeding on agricultural pests. The Hoopoe is respected and appreciated by Muslims because it is mentioned as Quranic bird in verse 20 of the Surat Al-Naml in the Holy Quran.

\section{White or Pied Wagtail (Motacilla alba)}

The White Wagtail (locally known as Abu Fasada or Kirkizan) is heavily widespread in the fall and winter seasons in the Gaza Strip. It is the most visible among birds in all areas of the Gaza Strip, including MC-IUG. The species is very familiar to all Palestinians who usually see it feeding on insects and other invertebrates. The bird is heavily exposed locally to hunting by children using wirenetting for hobby and sometimes eating purposes. By the end of the winter, the numbers of the White Wagtail are gradually decreasing to be replaced by the Yellow Wagtail (Motacilla flava) as a summer visitor to the country.

\section{Yellow-vented Bulbul (Pycnonotus xanthopygos)}

The Yellow-vented Bulbul is characterized by its beautiful voice and singing. The bird is very common throughout the year among the trees and bushes of public parks, agricultural orchards and the gardens of houses and institutions including MC-IUG (Figure 4.G). Students of IUG enjoy watching the bird and listening to its distinctive voices in the university's courtyards. The bird nests often contain three purple eggs as they were encountered many times at MC-IUG. Despite the advantages of this bird as a wonderful biodiversity creature in the Palestinian environment, some Gazan famers consider it as an undesirable pest because it feeds on their agricultural fruits.

\section{Spotted Flycatcher (Muscicapa striata)}

The Spotted Flycatcher is a migratory passerine of small-size. It is an aerial insectivore in the sense that it hunts and feeds on flying insects; especially flies, in the air, using its dark-colored tapered beak. The bird is sometimes 
seen perching on tree and shrub twigs and branches of gardens, public parks, agricultural orchards and MC-IUG.

\section{Graceful Prinia (Prinia gracilis)}

The Graceful Prinia is one of the densely populated species in the Gaza Strip. It prevails in habitats rich in low shrubby covers including that of MC-IUG. The bird is characterized by its long tail that is decorated in black and white, and is therefore a familiar bird for both adults and young Palestinians. The bird, like other warblers, feeds on insects and other invertebrates that predominate in its ecological habitats.

\section{Palestine Sunbird (Nectarinia osea)}

The Palestine Sunbird is considered the national bird in Palestine. Although the bird is endemic in Palestine and its surrounding countries, it has a least concern from a conservation point of view. This small bird (6-8 grams) is similar to the Hummingbird of America in form and behavior. It has a long black and curved beak that harmonizes with its feeding adaptation on the nectar of flowers of different plants in the Gaza Strip including the Tobacco Tree (Nicotiana glauca).The bird may also feed on some fruits and insects. Inside the boundaries of the MC-IUG, students usually enjoy seeing this endemic bird in pairs imbibing the nectar of flowers with unique skills. The larger male is usually characterized by its dark color, which is decorated with other colors such as blue and green, while the female has a brownish color (Figures 4.HI).

\section{Red-backed Shrike (Lanius collurio)}

The Red-backed Shrike is so named because the overall color of the upper parts of the male is reddish (Figure 4.J). The bird lives on different trees and shrubs in various environments in the Gaza Strip, including MC-IUG. The bird deserved the title of "butcher bird" because it bites its preys (insects, lizards, young birds, etc.) in a violent manner. Globally, the bird has a least concern category from a conservation point of view.

\section{Eurasian Jay (Garrulus glandarius)}

The Eurasian Jay (locally known as Zureiki) belongs to the ravens and is characterized by its side colors that distinguish it in its surroundings (Figure 4.K). The bird lives mainly in woody jungles and forests of Palestine and neighboring countries. In the Gaza Strip, the Eurasian Jay is frequently seen in many urban environments such as farms, parks, gardens and MC-IUG. The bird seems to feed on a variety of invertebrates in addition to seeds and fruits. The bird is annoying to local people in the sense that it produces loud voices in its existence places. Sometimes, the bird is locally trapped for unclear reasons.

\section{Hooded Crow (Corvus corone)}

The Hooded Crow is a familiar bird to all Palestinians. It prevails in forests, agricultural areas, Wadi Gaza, wastewater treatment plants and solid waste dumps of the Gaza Strip. In early hours of the morning, the bird is commonly seen roaming the passages and playgrounds or occupying the tops of trees and high buildings of the MCIUG (Figure 4.L). The bird is omnivore; feeding on what it finds during its search. From an ecological point of view, crow species play a capital role in cleaning up the dead animals and controlling the populations of harmful insects and other rodents in the Palestinian environment. The Crow (locally known as Ghurab) is respected by Muslims because it is a Quranic bird mentioned in verse 31 of the Surat Al-Maidah in the Holy Quran. Here, it is mentioned as the first teacher of humanity on how to bury bodies in the ground to protect human life from air pollution.

\section{Indian or Common Mynah (Acridotheres tristis)}

The Indian Mynah, which is locally known as "Yasimina", is an invasive or exotic species coming from Southeast Asia (India, Pakistan and Burma) to the Middle East countries including Palestine 15 years ago. This controversial bird became a successful breeder in those Middle East countries. The bird now inhabits all the Gaza Strip environments, especially the urban ones (Figure 4.M). The bird lives in pairs or in small groups, and is easily recognizable by its disturbing sounds. The voice of the Indian Mynah is commonly heard intensively from high buildings, towers, trees and electricity poles in MC-IUG and the whole Gaza Strip. Moreover, couples of the bird, along with couples of the Hooded Crow (Corvus corone) are commonly seen roaming the green grassy playground of IUG. When flying, the bird can be easily identified by its large white patch appearing below the wings. Environmentally, the bird is aggressive because it destroys and occupies the nests of other birds including the very common House Sparrow (Passer domesticus). It is considered as a pest by farmers because of its common attack to crops and agricultural fruits. The Indian Mynah is hunted in the Gaza Strip and sold cheaply at pet bird shops. The omnivorous nature of the species seems to widen its home range and geographical expansion. The bird builds its nest in the cavities of trees and buildings of MC-IUG.

\section{House Sparrow (Passer domesticus)}

This social bird is one of the most common birds in the world. The House Sparrow is named so because of its proximity to the urban and rural human dwellings. It lives in large numbers in public parks, gardens and streets, agricultural lands and marginal areas. It is considered the most frequent bird on MC-IUG. The bird is known to build its nest in the burrows of buildings and the cavities of trees and shrubs. It feeds on grains, seeds, insects and other food items available in its environment. In the Gaza Strip, the bird is commonly trapped by children using metal traps for eating and rearing purposes.

\section{Goldfinch (Carduelis carduelis)}

The Goldfinch is locally and globally characterized by its distinctive appearance and beautiful voice. This makes the bird a target for hunting and trapping by Gazans in the whole Gaza Strip. It is a common phenomenon to see the bird caged in nearly all pet bird shops. Though it is rare nowadays, the Goldfinch can be intermittently seen in the 
agricultural orchards, open spaces, gardens, public parks of the Gaza Strip including MC-IUG. The bird feeds on seeds and insects in its places of residence. The numbers and populations of the Goldfinch have decreased in an alarming fashion since decades in the Gaza Strip because of overhunting, urban encroachment and destruction of ecological habitats. The Goldfinch is brightly colored with its face having red, black and white colors. Although the bird prevails in Europe, North Africa and Western Asia, it was brought into many parts of the world for the same reasons mentioned above.

\section{Discussion}

The current study shows 56 species of bird fauna at MC-IUG; the majority of which were reported in previous studies carried out in the Gaza Strip (Abd Rabou 2005, 2011a,b; Yassin et al. 2006; Abd Rabou et al. 2007). The importance of this study comes from the fact that it is the first study targeting an urban environment in the Gaza Strip, represented here by MC-IUG, which houses buildings with different heights, trees, shrubs, grasses and a playground. All these structures introduce, in one way or another, accommodation, protection, roosting, resting, nesting, mating and feeding purposes to birds. The birds encountered at MC-IUG reflect largely those birds prevailing in other urban environments of the Gaza Strip like streets, hospitals, universities, schools, orchards etc. (Abbas 2016; Radwan 2017; Abd Rabou 2018). The current study showed that $62.5 \%$ of the bird species encountered are passerines and the rest (37.5\%) falls within the rank of non-passerines. A great proportion of the passerine and non-passerine species listed in the current study is frugivores and has very important roles in seed dispersal (Corlett 2017) in Palestine, where the agriculture is its backbone.

The nature of vegetation at MC-IUG, as in other urban environments, which is often devoid of water bodies, sand dunes and other natural habitats, determines the nature and variety of birds encountered. Most of these birds often depend on trees, shrubs and buildings in their life affairs. The small size of the majority of birds recorded is somewhat related to their movement, hiding, feeding, resting and nesting characters provided by the crowded crowns of trees and shrubs (Table 1). Nevertheless, the usual small size of passerine species and the diversity of native and exotic trees and shrubs they occupy in MC-IUG sometimes make them hidden and as a result unseen by the surveyor and thus not recorded. No doubts that the study of birds in open environments with multiple habitats and niches will certainly show different proportions of bird categories like raptors and a variety of waterfowl and wader species, determined mostly by the nature of these environments. Some of such categories are commonly subject to poaching and hunting by bird hunters in different aquatic or semi-aquatic habitats within the Gaza Strip environment (Abd Rabou et al. 2007; Abd Rabou 2011 a, b, c) and other Palestinian environments (Yom-Tov 2003).

The diversity of wildlife including bird fauna in Palestine comes as a reflection of its geographic position in addition to its great diversity of climates, terrain, ecosystems and habitats (Qumsiyeh 1996). Many migratory birds depend on the coastal environment of the Gaza Strip as a stopover point prior to continuing their annual migration from Eurasia to Africa and vice versa (Euroconsult and IWACO 1994; UNEP 2003; MedWetCoast 2003). This can largely be attributed to the fact that the Gaza Strip is a bottleneck of migratory birds coming from Eurasia to Africa and vice versa. Moreover, the Gaza Strip is studded with various varieties of unique agricultural crops, vegetables, fruits and grains. For example, The Al-Mawasi ecosystem $\left(14 \mathrm{~km}^{2}\right)$ is a unique agricultural and natural ecosystem of coastal Palestine in the far south-west of the Gaza Strip along the Mediterranean Sea. It contributes significantly to attracting of biodiversity, especially bird fauna, whether they are residents or migrants. Wadi Gaza, as another example, provides habitats and multi-purpose niches for a variety of vertebrate fauna as indicated by MedWetCoast (2003); Abd Rabou (2005 and 2011a).

The apparent decline of many bird species in the Gaza Strip could be partially attributed to overpopulation and residential expansion at the expense of natural ecosystems, transference of ecological habitats into cultivated systems, poaching and trapping, wastewater drainage and poor implementation of environmental laws and legislations. In this regard, D'Andrea et al. (1999) pointed out that the replacement of natural habitats by cultivated areas has been changing the animals and plant communities, mainly in relation to the composition and abundance of wildlife species. Hanowski and Niemi (1993) showed that discharging of wastewater into the Houghton lake wetland in U.S.A. affected adversely bird species and numbers.

Poaching and hunting of wildlife are common practices in the Gaza Strip. The Common Quail (Coturnix coturnix), Goldfinch (Carduelis carduelis), in addition to many raptor and dove species are commonly poached and hunted using different trapping means. Euroconsult/IWACO (1994), MedWetCoast (2003), UNEP (2003) and Abd Rabou et al. (2007) pointed out that the hunting of birds and other wildlife species along the Mediterranean coast of the Gaza Strip is an escalating phenomenon. Such illegal hunting or over-hunting activities were known to threaten many wildlife species worldwide (Kerley et al. 2000; Yom-Tov 2003; Sert and Erdogan 2004). This catastrophic position argues the responsible Palestinian parties to regulate wildlife hunting activities in order to protect wildlife in a sustainable fashion.

The Spur-winged Plover Vanellus spinosus is an actual breeder in different localities of the Gaza Strip. Its occurrence in such urban environments like MC-IUG and public parks could be attributed to its widespread nature including the storm water collection ponds and farms that are not far a way from human dwellings and urban environments in spite of its preference to breed and build its ground nests in agricultural and semi-aquatic places (Hassan 2001).

The Palestine Sunbird (Nectarinia osea) is the only endemic species in Palestine as it inhabits different natural, rural and urban environments rich in flowering plants (Porter et al. 1996; Shirihai 1996). Although the bird is 
commonly seen imbibing the nectar of flowers of many plants at MC-IUG, the Tree Tobacco (Nicotiana glauca) constitutes a major food source for the species in the east Mediterranean (Tadmor-Melamed 2004) including the Gaza Strip (Abd Rabou et al. 2007). The role of many sunbirds (Nectariniidae) was documented among passerine birds involved in seed dispersal (Corlett 2017).

Compared to other bird species, the House Sparrow (Passer domesticus) seems to have the highest abundance at MC-IUG and the whole Palestinian environment. This could be attributed to the bird's feeding habits and high reproduction affinity. The bird exploits a wide range of food materials and nesting places in different habitats including the urbanized environments as indicated by Jonsson (1999).

The doves encountered in the current study; Rock Dove (Columba livia), Laughing Dove (Streptopelia senegalensis) and Turtle Dove (Streptopelia turtur) are commonly found everywhere in the natural and urban environments of the Gaza Strip. Many other dove species encountered in other studies like that of Abd Rabou et al. (2007) were not included in the current study because of their limited number and/or preference to more wild, agricultural or even open habitats. However, the easy hunting habit of doves by Gazans could be attributed partially to the fact that they feed primarily at man-made sites and infrequently at natural sites.

The Common Myna (Acridotheres tristis) became a common bird seen at MC-IUG and the whole Gaza Strip. It is an aggressive and noisy species as it attacks and occupies the nests of other birds including the House Sparrow (Passer domesticus) at MC-IUG. Gazans usually ask the responsible and scientific parties regarding the wide distribution and problems associated with this invasive bird. According to Holzapfel et al. (2006), the species is listed as one of the 100 worst invading species worldwide and is known to pose negative impacts on native birds and to cause problems to humans and the environment. The species has been increasingly noted in the Gaza Strip and the whole Palestine since the beginning of the current century. Analogous to other wildlife species in the Palestinian environment, the spread of the species could be attributed to deliberate introductions or by accidentally escaping cage birds from zoological gardens or due to natural range expansion from neighboring regions (Richardson 1992; Qumsiyeh 1996 and Gregory 2002).

Finally, the author recommends carrying out more research on wildlife inhabiting the urban environments of the Gaza Strip. A greening strategy of the Gaza Strip is a crucial factor in enhancing the environmental health aspects of Gazans and attracting more biodiversity components in times the whole Gazans suffer from the severe life conditions imposed by the Israeli occupation and blockades.

\section{ACKNOWLEDGEMENTS}

My thanks are due to Ayman W. Dardonah, Ms. Mandy M. Sirdah and Ms. Lara M. Sirdah who have taken the wonderful photos in the field to make the present study more expressive and more illustrative.

\section{REFERENCES}

Abbas A. 2016. An ecological Survey and assessment of median trees and shrubs as an urban biodiversity component in Gaza city, Palestine. [Thesis]. Islamic University of Gaza, Palestine.

Abd Rabou AN. 2005. An Ecological Survey and Assessment of Wadi Gaza Nature Reserve, Gaza Strip - Palestine, with Particular Emphasis on Wildlife. [Dissertation]. Department of Environmental Studies, Faculty of Science and Technology, School of Life Sciences, Al-Neelain University, Sudan.

Abd Rabou AN. 2011a. On the ecology of Wadi Gaza, Gaza Strip: Survey and assessment (Wildlife is focused). LAP Lambert Academic Publishing, Germany.

Abd Rabou AN. 2011b. Notes on some Palestinian bird fauna existing in the zoological gardens of the Gaza Strip. Amer Eur J Agricult Environ Sci 11 (2): 159-172.

Abd Rabou AN. 2011c. Environmental impacts associated with the Beit Lahia wastewater treatment plant, North Gaza Strip, Palestine. Middle-East J Sci Res 7 (5): 746-757.

Abd Rabou AN. 2018. Trees and shrubs prevailing in the urban green spaces of the Gaza City in Palestine. IUG J Nat Stud 26 (2): 1-9.

Abd Rabou AN, Radwan ES. 2017. The current status of the date palm (Phoenix dactylifera) and its uses in the Gaza Strip, Palestine. Biodiversitas 18 (3): 1047-1061.

Abd Rabou AN, Yassin MM, Al-Agha MR, Hamad DM, Ali AS. 2007. The avifauna of Wadi Gaza Nature Reserve, Gaza Strip - Palestine. Islamic Univ J (Ser Nat Stud Eng) 15 (1): 39-85.

Abu Shammalah M, Baha El-Din M. 1999. Birds of Gaza. Darwish Consulting Engineers Ltd, Gaza.

Baha El Din M, Atta J. 1990. The world of birds in Egypt. International Council for Bird Preservation / The Egyptian Wildlife Service for the Conservation Education Center in the Giza Zoo, Cairo [Arabic].

Bibby C, Jones M, Marsden S. 1998. Expedition field techniques: Bird surveys. Expedition Advisory Center, Royal Geographical Society (with the Institute of British Geographers), London.

Bock CE, Bock JH, Bennett BC. 1999. Songbird abundance in grasslands at a suburban interface on the Colorado high plains. Stud Avian Biol 19: 131-136.

Brooke M, Birkhead T. 1991. Cambridge encyclopedia of ornithology: A Cambridge reference book. The Royal Society for the Protection of Birds (RSPB), Cambridge University Press; London.

Corlett RT. 2017. Frugivory and seed dispersal by vertebrates in tropical and subtropical Asia: An update. Global Ecol Conserv 11: 1-22.

Cottridge DM, Porter R. 2000. A photographic guide to birds of Israel and the Middle East. Steimatzky Ltd.

D’Andrea P S, Gentile R, Cerqueira R, Grelle C V, Horta C, Rey L. 1999. Ecology of small mammals in a Brazilian rural area. Revisita Bras Zool 16 (3): 611-620.

Disi AM, Hatoug-Boran A. 1990. Wild birds of Jordan. The Royal Society of Nature Conservation (Jordan), Amman/International Counsil for Birds Preservation. [Arabic].

Dunn EH. 2002. Using decline in bird populations to identify needs for conservation action. Conserv Biol 16 (6): 1632-1637.

Euroconsult and IWACO. 1994. Gaza environmental profile (Part I): Inventory of resources. Palestinian Environmental Protection Authority, Gaza Strip-Palestine.

Evans M, Amr Z, Al-Oran RM. 2005. The Status of Birds in the Proposed Rum Wildlife Reserve, Southern Jordan. Turk J Zool 29: 17-25.

Forshaw J, Howell S, Lindsey T, Stallcup R. 1999. Birding: The Nature Company Guides. Time Life Books, USA.

Gilroy JJ, Gill JA, Butchart SHM, Jones VR, Franco1 AMA. 2016. Migratory diversity predicts population declines in birds. Ecol Lett 19: $308-317$.

Gregory G. 2002. The captive origin of bird species in Kuwait. Sandgrouse 24: 122-129.

Guptha MB, Kishore S, Prasad NVS, Rao PVC. 2015. Birds of Seshachalam biosphere reserve, South-eastern Ghats of Andhra Pradesh, India. Intl J Biodiv Conserv 7 (12): 435-452.

Hamad DM. 1998. Bird fauna in Dinder National Park. Sudan Notes Rec 2: $187-203$. 
Hanowski J, Niemi G. 1993. Effect of sewage effluent on bird abundance and species composition in Northern Minnestonia wetland Minnestonia Acad Sci J 57 (2): 5-10.

Harrison C, Greensmith A. 1993. Birds of the World. $1^{\text {st }}$ American ed. DK Publishing. Inc., London.

Hassan MA. 2001. Breeding habits of the spur-winged plover Vanellus spinosus in Sunt Forest Bird Sanctuary. [Thesis]. Zoology Department, University of Khartoum, Sudan.

Holzapfel C, Levin N, Hatzofe O, Kark S. 2006. Colonization of the Middle East by the invasive Common Myna Acridotheres tristis L. with special reference to Israel. Sandgrouse 28 (1): 44-51.

Jonsson L. 1999. Birds of Europe with North Africa and the Middle East Christopher Helm (Publishers) Ltd., London.

Kerley GIH, Watson JJ, Boshoff AF. 2000. Seasonal abundance, reproduction and hunting of Common Quail Coturnix coturnix in the Eastern Cape Province, South Africa. African J Ecol 38 (4): 303-311

Liven-Schulman I, Leshem Y, Alon D, Yom-Tov Y. 2004. Causes of population declines of the lesser kestrel Falco naumanni in Israel. Ibis 146 (1): 145-152

Mahmoud ZN, Tahir YF, Hamdeen HM. 2015. Birds of El Ga'ab Depression, Sudan. Eur Acad Res 3 (4): 4408-4415.

Marwat SK, Khan KU, Rehman F, Shoaib M. 2014 Medicoethnzoological studies of the Quranic birds (Aves) from scientific perspectives. PharmaBitika 1 (1): 158-172.

MedWetCoast. 2003. Management plan: Wadi Gaza. Project for the Conservation of Wetland and Coastal Ecosystems in the Mediterranean Region - MedWetCoast, Gaza.

Perktas, U, Ayas, Z. 2005. Birds of Nallihan Bird Paradise (Central Anatolia, Turkey). Turkish J Zool 29: 45-59.

Perlman Y, Meyrav J. 2009. Checklist of the birds of Israel. Israel Ornithological Center, Society for the Protection of Nature in Israel (SPNI), Israel.

Pomeroy D. 1992. Counting birds. AWF technical handbook series 6 , African Wildlife Foundation (AWF), Nairobi, Kenya.

Porter RF, Christensen S, Schiermacker-Hansen P. 1996. Field guide to the birds of the Middle East. T and AD Poyser, London.
Qumsiyeh MB. 1996. Mammals of the Holy Land. Texas Tech. University Press, U.S.A.

Radwan ES. 2017. The Current Status of the Date Palm Tree (Phoenix dactylifera L.) and its Uses in the Gaza Strip, Palestine. [Thesis]. Islamic University of Gaza, Palestine.

Richardson C. 1992. Escapees and introductions in the United Arab Emirates. Phoenix, 9: 13-15

Rudra NP, Udit Pratap D, Rajesh KM, Arun KM. 2013. Checklist of birds in and around Ansupa Lake, Odisha, India. Intl Res J Environ Sci 2 (11): 9-12.

Selmi S, Boulinier T. 2003. Breeding bird communities in southern Tunisian oases: The importance of traditional agricultural practices for bird diversity in a semi-natural system. Biol Conserv 110: 285294.

Sert H, Erdogan A. 2004. The avifauna of Termessos National Park (Antalya - Turkey). Turkish J Zool 28: 134-145.

Shirihai H. 1996. The birds of Israel. Academic Press, New York.

Sulieman Y; Pengsakul T, Afifi A, Zakaria M.A. 2016. Bird diversity in Shendi area, Sudan. Intl J Res Granthaalayah 4 (6): 55-63.

Tadmor-Melamed H, Markman S, Arieli A, Distl M, Wink M, Izhaki I. 2004. Limited ability of Palestine Sunbirds Nectarinia osea to cope with pyridine alkaloids in nectar of Tree Tobacco Nicotiana glauca. Funct Ecol 18: 844-850.

UNEP. 2003. Desk study on the environment in the Occupied Palestinian Territories. United Nations Environment Program (UNEP), Nairobi, Kenya.

Yassin MM, Abd Rabou AN, Al-Agha MR. 2006. Preliminary survey of terrestrial vertebrate fauna and people's awareness towards wildlife in the Northern Governorate of the Gaza Strip. Al-Azhar Bull Sci Zool Bot 17 (1): 17-41.

Yom-Tov Y. 2003. Poaching of Israeli wildlife by guest workers. Biol Conserv 110: 11-20.

Yousif R.A. 2012. Abundance, Mayas preference and distribution of birds in Dinder National Park, Sudan. World's Vet J 2 (3): 27-32. 